\title{
Occupational Health Hazards among Workers in Ceramic Factories
}

\section{Asmaa Fathy Mahmoed ${ }^{1}$, Mahbouba Sobhy Abd El-Aziz ${ }^{2}$ and Taisser HamidoAbo sree ${ }^{3}$}

(1) Nursing Specialist in Fever Hospital, (2) Prof. of Community Health Nursing, Faculty of NursingBenha University, and (3) Lecturer of Community Health Nursing, Faculty of Nursing- Benha University.

\begin{abstract}
:
Background: Ceramic industry had a variety of biological, chemical, physical, an ergonomic and psychological hazard that cause dangers to workers during work. The aim of the study was to assess the occupational health hazards among workers in Ceramic Factories. Research Design: A descriptive research design was utilized to conduct this study. Setting: This study was conducted at Ceramic Factory at Queisna City, Menoufia Governorate. This is the only Factory found in Menoufia Governorate. The Sample: Systematic random sample was used in this study for worker in Ceramic Factory. The study sample constituted 150 workers from the total 1400 workers in the Factory. Tools: Two tools were used I): An interviewing questionnaire which consisted of three parts to assess workers' socio demographic characteristics, work experience, health problem of workers and knowledge about occupational health hazards and II): Observational checklist which consisted of two parts to assess and observe the characteristics of the work environment safety and sanitation condition, and the workers' practices regarding prevention of occupational health hazards. Results: The age of $40.7 \%$ of studied workers was 30 years and more with mean age $32.54 \pm 8.47$ years. As past medical history, $53.3 \%$ of them had allergic rhinitis and sinusitis and $74.7 \%$ of them had chronic cough as present medical history. In addition, $19.3 \%$ of them had good total knowledge scores related to occupational health hazards, $82.7 \%$ of studied workers had satisfactory practices regarding prevention of occupational health hazard. Conclusion: Less than three quarters of studied workers had average total knowledge and the majority had satisfactory practices regarding prevention of occupational health hazard. There was no statistically significant relation between the studied ceramic workers' total knowledge and their total practices regarding occupational health hazards. Recommendations: Develop and implement training program for ceramic workers to improve their knowledge and practices toward occupational health hazards.
\end{abstract}

Key Words: Ceramic Factory, Workers, Occupational Health Hazards

\section{Introduction}

Occupational health refers to the identification and control of the risks arising from physical, chemical, and other workplace hazards or placing and maintenance of the workers in an occupational environment adapted to physiological and psychological capabilities in order to establish and maintain safe and healthy working environment (Friend \& Kohn, 2018).
Occupational health hazards are the risks to the health of workers usually arising out of employment. Occupational health hazards also refer to process or situation that causes accidents or disease at work place. Occupational health hazards are brought about by unsafe work conditions and unsafe work behaviors. Workplace hazards or injuries are preventable with the use of 
appropriate occupational safety and health services (Jain et al., 2018).

Occupational health hazards in the workplace can be found in a variety of forms, including chemical, physical, biological, psychological, and non-application of ergonomic principles. Because of the multitude of hazards in most workplaces and the overall lack of attention given to health and safety by many employers, work- related accidents and diseases continue to be serious problems in all parts of the world (Moursy \& Asharaf, 2017).

There are 2.9 billion workers are exposed to hazardous risks at work places. Annually there are two million deaths that are attributable to occupational diseases and injuries in Ceramic Factories all over the world. Developing countries have more fatal accidents than industrialized nations, so that emphasizing the need for health and safety education programs that focus on prevention occupational health hazards in Ceramic Factories (Pretty et al., 2016).

Ceramics Factories are establishments that are aimed at the production of artifacts from clay and alloying elements such as gravel, making plastic and easy mix shape when wet. After being subjected to the drying process to remove moisture from the material, the molded part is exposed to temperatures of $1,000{ }^{\circ} \mathrm{C}$, which provides rigidity and of the mass. In some situations, it is also made impregnation varnish on the outer surface of the part (Occupational Safety and Health Administration (OSHA), 2019).

Occupational health problems occur in Ceramic Factory can include cuts, accidents, and musculoskeletal diseases, respiratory diseases, hearing loss, circulatory diseases, stress related disorders, vision problems, or blindness illness caused by breathing, touching or ingesting unsafe substances, communicable diseases and others.
Workers have tried to stay fit, reduce stress, set up work area properly and use the right equipment (Smits et al., 2018).

Occupational Health Nurses (OHN) can play a major role in protecting, preventing and improving the health for workers in ceramic factory. Occupational health nursing is one that is focused on health promotion, illness and injury prevention, and the protection of workers from occupational and environmental hazards. Occupational health nurses, who prevent, diagnose and treat occupational and environmental diseases and injuries that occur in ceramic factory all times (Noorian et al., 2017).

\section{Significance of the study}

The ceramic and animating materials industries represents one of the seven major industries in the Egyptian market with a large number of workers. Ceramic industry is one of the most ancient industries on the planet. Sixty six point six of the ceramic workers in Egypt exposed to free silica level above $5 \%$ significantly showed changes in x-ray films. The ceramics industry in Egypt shows that $70 \%$ of the 40,000 workers in Egypt working in the ceramic industry with lung diseases and respiratory system, some of these disease lead to pulmonary embolism, in addition to diseases that afflict the residents near the factories with asthma, allergies and difficulty breathing. The work in the Ceramic Factory requires the development of theoretical and scientific knowledge about the protective measures in medicine and safety. This study have benefit to determined hazards and eliminate that hazards to workers. (Moganti, 2016).

\section{Aim of the study}

The aim of the current study was to assess the occupational health hazards, knowledge and practices among workers in Ceramic Factories.

\section{Research Questions}

1. What are the worker's health problems in Ceramic Factory? 
2. What is the workers' knowledge related to occupational health hazards in Ceramic Factory?

3. What are the worker's practices regarding using of personal protective devices in Ceramic Factory?

4. What is the relation between socio demographic characteristics of worker in Ceramic Factory and the knowledge and practices related to occupational health hazards?

5. What is the relation between workers' knowledge and practices in Ceramic Factory?

\section{Subject and Methods}

\section{Research Design:}

A descriptive research design was used in carrying out this study. Descriptive research method that describes the characteristics of the population that is being studied and focuses more on the "what" of the research subject rather than the "why" of the research subject.

\section{Setting:}

This study was conducted at Ceramic Factory at Queisna City, Menoufia Governorate. This is the only Factory found in Menoufia Governorate, their weren't Ceramic Factory in Qalubia Government and the workers who work in this Factory exposed too many health hazards-

The work in the Factory is about three shifts for seven days,8-hours/day. The total workforce is approximately 1400 workers distributed as following: Preparation and processing of ceramic body (150), Glaze preparation (50), Glaze application (200), Firing (50), Astoring (200), Maintenance (50), Transport and distribution (50), Administration (650).

\section{Sample:}

A systematic random sample was used in this study for worker in Ceramic Factory. The sample was chosen from the previous mentioned setting, by selecting every fifth workers in each department from workers' list except for workers in the administration department because these workers are not exposed to hazards as other parts. The study sample constituted 150 workers from the total 1400 workers in the Factory.

\section{Data collection tools:}

\section{The first tool: An interviewing questionnaire:}

It consisted of the following two parts:

The first part: -a) socio demographic characteristic of ceramic workers which include 7 questions about (age, residence, educational level, monthly income, marital status, smoking and family type).

b) Working experience of ceramic workers which included 4 questions about (working hours/day, previous years of experience at Ceramic Factory, training courses taken related to work in Ceramic Factory and numbers of training courses).

The second part: -Health problem of workers in Ceramic Factory which included:

a) The past medical history of workers related working in Ceramic Factories which included 6 questions about (respiratory system disease, bone disease, cancer diseases, eyes diseases, skin diseases and ears diseases).

b) Present medical history of workers related to working in Ceramic Factories which included 7 questions (difficulty breathing, chronic cough, pain in the upper back, neck pain, lower back pain, shoulder pain, change in skin color).

The third part: (A) it consisted of workers' knowledge about occupational health hazards in Ceramic Factory which included 8 questions such as (meaning of occupational health hazards, types of occupational health hazards which workers are exposed in the Ceramic Factory, physical health hazards, chemical health hazards, biological health hazards, psychological health hazards, ergonomic health hazards, method of prevention of occupational health hazards). 
(B): It's consisted of workers' knowledge about how to deal with some health problems and injures occurring in Ceramic Factory. It included 6 questions such as (difficulty breathing, burn, hemorrhage, fractures, shocks and fainting).

\section{Scoring system:}

The scoring system for ceramic workers' knowledge was calculated as the follows: (2) scores for the correct and complete answer, while (1) score for the correct and incomplete answer and (0) for don't know for each question of knowledge. The total scores of items were summed up which equal 28 scores and the total was divided by the number of the items, these scores were converted into percent score. The total knowledge scores were considered good if the score of the total knowledge is $>75 \%$ (> 21 points), average if it is equals $50-<75 \%$ (14$<21$ points) and poor if it is less than $50 \%$ (14 point).

\section{The Second tool: - An observational} checklist, which consists of two parts as the following :

The first part: An observational checklist to assess and observe the work environment safety and sanitation condition according to the standards of Egyptian industrial safety. It was adapted from (Ramos et al., (2018) after reviewing the related literature. It included 22 items (good lighting for safety services, good ventilation, good monitoring of workers to control noise when using machines, the presence of thermometers to measure the temperature of the place, clean floor, dry and free from dust, floor free from cracks and crevices, clean place and wide, water and soup are available for continuous hand washing, separate places for exchange of clothes, bathing, washing facilities and place for eating.- The tool also assesses the availability of special drying towel for each worker, wastes disposal, arranging stairs and free from cracks, , near specific hospital or clinic for workers, available and complete first aid bag, first aid kit is easy to reach for a worker, safety alarm to protect workers from hazards, training persons to bring and use the tools in the work in a timely manner. There are more than one fire extinguisher in separate places, security personnel trained to use fire extinguishers in neared places and there is an emergency exit known to the workers).

The scoring system for work environment safety and sanitary condition:-The available item was scored 1 and if unavailable 0 score was given.

The second part: $-A)$ observational checklist to assess and observe the worker's practices during using the different personal protective equipment that include 9 items( overall uniform, head cover(cap), safety face glass shield, eye goggles, gloves, protective apron, safety boots, respiratory mask, and ear muff).

\section{The scoring system:}

Each practice was given (1) score if available and used, and (0) if not available. The scores of items were summed up and the total was divided by the number of the items, these scores were converted into percent score. The total scores were considered satisfactory if the score of the total practices was more than or equal $60 \%(>5)$ and considered unsatisfactory if it is less than 60 $\%(<5)$.

B) Observational checklist to assess and observe practices of worker to prevent occupational health hazard in Ceramic Factory. It was adapted from Colovic (2018) that include 5 items (Aprevention of physical health hazard, (Bprevention of chemical health hazard,(Cprevention of biological health hazard, (Dprevention of an ergonomic health hazard, (Eprevention of psychological health hazard).

\section{Scoring system:}

Each practice got (1) score for done and (0) score for not done. The scores of items were summed up and the total was divided by the number of the items, giving mean score for the part. These 
scores were converted into percent score. The total practices scores were considered satisfactory if the score of the total practices is more than $60 \%(>25)$ and considered unsatisfactory if it is less than $60 \%(<25)$.

\section{Content validity and reliability of the tools:}

The tools were reviewed for comprehensiveness, appropriateness and legibility by three experts of Faculties Nursing Staff from the Community Health Nursing Specialty. The experts ascertained the face and content validity of the tools. The reliability was done by Cornbrash's Alpha coefficient test which revealed that each of the two tools consisted of relatively homogeneous items as indicated by the moderate to high reliability of each tool. The internal consistency of knowledge was 0.83 , and practice was 0.832 .

\section{Ethical consideration:}

Consent has been obtained orally from each worker before conducting the interview and given a brief orientation to the purpose of the study. They were also reassured that all information gathered would be confidential and used only for the purpose of the study. No names were required on the forms to ensure anonymity and confidentiality. They were also informed about their right to withdraw at any time from the study without giving any reasons.

\section{Pilot study:}

A pilot study was conducted on $10 \%$ of the studied workers (15workers) to test the content, applicability and simplicity of the tool using the interviewing questionnaire and observational checklist. Based on the pilot study the tools were organized. Organization of the tool included rephrasing, rearrangement of some questions. After refinement and organization, the final forms of the tools were developed. This pilot study was carried in two weeks before starting the study and those who shared in the pilot study were included in the studied sample.

\section{Field work}

Data were collected over 4 months from the start of March of 2020 to end of June 2020. The investigator visited the Ceramic Factory for 2 days/week (Saturday/Tuesday) from 9:00 am to 2:00 pm. The investigator explained the purpose and importance of the study to the workers and obtained their consent. The investigator collected data from the workers using tool one and observed the workers' practices using the observational checklist. The average number of interviewed workers was between 5-6 workers/day depending on their response to the interviewers, each interviewed worker takes about 30 to 40 minutes to fill the sheet depending upon their understanding and response.

\section{Statistical analysis:}

Computerized data entry and statistical analysis were done using Statistical Package for Social Science (SPSS), version (25). Descriptive statistics (frequency, percentages, mean and standard deviation) were applied as well as inferential statistics using Chi-square

Statistical significance was considered:

- Significant result when P- value <0.05.

- Highly significant result when P- value $<0.001$.

- Non- significant result when P-value>0.05.

\section{Results:}

Table (1): Shows that; $40.7 \%$ of studied workers their age was 30 years and more with a mean age $32.54 \pm 8.47$ years. Majority of them $(78.0 \%)$ were living in rural area, and 34\% hadn't enough monthly income, $21.0 \%$ of them were married, $58.7 \%$ were smokers and $34 \%$ had secondary education.

Table (2): Shows that $78.4 \%$ of studied workers worked for 6-8 hours /day at Ceramic Factory, and $40 \%$ of them had one to less than six years of work experience in this field. Also, $54.6 \%$ of them had training course on using of personal protective equipment, and $43.3 \%$ of them had only one training course in this factory. 
Table (3): Regarding past medical history, this table shows that $53.3 \%$, of studied workers in Ceramic Factory had allergic rhinitis and sinusitis from respiratory disease, $37.3 \%$ of them had fracture and $37.4 \%$ of them had lung cancer. As well as $42.6 \%$ of studied workers had irritation of the membrane of the eye, $38.7 \%$ of them had skin inflammation and $41.3 \%$ of them had hearing loss.

Table (4): Shows that $74.7 \%$ of studied workers had chronic cough, while $68.7 \%$ of them had difficulty breathing and $9.3 \%$ of them had change in skin color.

Table (5): Shows that $46.7 \%$ of the studied workers had good monitoring of workers to control noise when using machines, while $7.3 \%$ of them worked in Factory with good lighting for safety services.

Table (1): Frequency distribution of studied workers according to their socio demographic characteristics $(\mathbf{n}=\mathbf{1 5 0})$.

\begin{tabular}{|c|c|c|}
\hline Demographic Characteristics & No. & $\%$ \\
\hline $\begin{array}{l}\text { Age/ years } \\
20+ \\
30+ \\
40+ \\
<50 \\
\end{array}$ & $\begin{array}{l}25 \\
61 \\
48 \\
16\end{array}$ & $\begin{array}{l}16.7 \\
40.7 \\
32.0 \\
10.6\end{array}$ \\
\hline $32.54 \pm 8.47$ & & \\
\hline $\begin{array}{l}\text { Residence } \\
\text { Rural } \\
\text { Urban }\end{array}$ & $\begin{array}{l}117 \\
33\end{array}$ & $\begin{array}{l}78.0 \\
22.0\end{array}$ \\
\hline $\begin{array}{l}\text { Educational level } \\
\text { Not read and write } \\
\text { Read and write } \\
\text { Primary education } \\
\text { Secondary education } \\
\text { University education }\end{array}$ & $\begin{array}{l}8 \\
46 \\
36 \\
51 \\
9 \\
\end{array}$ & $\begin{array}{l}5.1 \\
30.7 \\
24.0 \\
34.0 \\
6.2 \\
\end{array}$ \\
\hline $\begin{array}{l}\text { Monthly income } \\
\text { Enough only } \\
\text { Enough and saved } \\
\text { Not enough }\end{array}$ & $\begin{array}{l}51 \\
42 \\
57 \\
\end{array}$ & $\begin{array}{l}34.0 \\
28.0 \\
38.0 \\
\end{array}$ \\
\hline $\begin{array}{l}\text { Marital Status } \\
\text { Single } \\
\text { Married }\end{array}$ & $\begin{array}{l}114 \\
36\end{array}$ & $\begin{array}{l}79.0 \\
21.0\end{array}$ \\
\hline $\begin{array}{l}\text { Smoking } \\
\text { Smoker } \\
\text { No smoker } \\
\text { Previous smoker }\end{array}$ & $\begin{array}{l}88 \\
52 \\
10\end{array}$ & $\begin{array}{l}58.7 \\
34.6 \\
6.7\end{array}$ \\
\hline
\end{tabular}


Table (2): Frequency distribution of studied workers according to their work experience (no=150).

\begin{tabular}{|c|c|c|}
\hline Working Experience & No. & $\%$ \\
\hline $\begin{array}{l}\text { Working hours/ day } \\
6-8 \text { hours } \\
<9 \text { hours }\end{array}$ & $\begin{array}{l}118 \\
32\end{array}$ & $\begin{array}{l}78.4 \\
21.6\end{array}$ \\
\hline $\begin{array}{l}\text { Previous years of experience at Ceramic Factory } \\
1- \\
6- \\
12- \\
16+\end{array}$ & $\begin{array}{l}60 \\
54 \\
25 \\
11\end{array}$ & $\begin{array}{l}40.0 \\
36.0 \\
16.7 \\
7.03\end{array}$ \\
\hline $\begin{array}{l}\text { Training courses which taken related to work in Ceramic } \\
\text { Factory } \\
\text { Introduction of work and knowledge about occupational healt } \\
\text { hazards } \\
\text { Using of personal protective equipment } \\
\text { Dealing with occupational safety emergencies } \\
\text { First aid }\end{array}$ & $\begin{array}{l}34 \\
82 \\
16 \\
18\end{array}$ & $\begin{array}{l}22.6 \\
54.6 \\
10.6 \\
12.2\end{array}$ \\
\hline $\begin{array}{l}\text { Number of training course } \\
\text { One course } \\
\text { Two courses } \\
\text { Three courses } \\
\text { More than four courses }\end{array}$ & $\begin{array}{l}65 \\
37 \\
28 \\
20\end{array}$ & $\begin{array}{l}43.3 \\
24.7 \\
18.7 \\
13.3\end{array}$ \\
\hline
\end{tabular}


Table (3): Frequency distribution of workers regarding their past medical history $(n=150)$.

\begin{tabular}{|c|c|c|}
\hline Past medical history & No. & $\%$ \\
\hline $\begin{array}{l}\text { Respiratory system diseases } \\
\text { Allergic rhinitis and sinusitis } \\
\text { Pulmonary Tuberculosis ( TB) } \\
\text { Bronchitis } \\
\text { Chest sensitivity } \\
\text { Chronic expectoration } \\
\text { Pneumonia }\end{array}$ & $\begin{array}{c}80 \\
40 \\
4 \\
7 \\
9 \\
10\end{array}$ & $\begin{array}{c}53.3 \\
26.9 \\
2.6 \\
4.6 \\
6.0 \\
6.6\end{array}$ \\
\hline $\begin{array}{l}\text { Bone disease } \\
\text { Fracture } \\
\text { Sprains and bruises } \\
\text { Accident and injuries } \\
\text { Slipped disc } \\
\text { Muscles strain }\end{array}$ & $\begin{array}{l}56 \\
46 \\
22 \\
16 \\
10\end{array}$ & $\begin{array}{l}37.3 \\
29.3 \\
10.4 \\
12.0 \\
11.0\end{array}$ \\
\hline $\begin{array}{l}\text { Cancer diseases } \\
\text { Mouth cavity cancer } \\
\text { Pharynx cancer } \\
\text { Lung cancer } \\
\text { Thyroid cancer } \\
\text { Bladder cancer } \\
\text { Skin cancer }\end{array}$ & $\begin{array}{l}18 \\
29 \\
56 \\
23 \\
24\end{array}$ & $\begin{array}{c}12 \\
19.3 \\
37.4 \\
15.3 \\
16.0\end{array}$ \\
\hline $\begin{array}{l}\text { Eyes diseases } \\
\text { Irritation of the membrane of the eye } \\
\text { Dry eyes } \\
\text { Allergy and eye inflammation } \\
\text { Entry of a foreign body into the eye } \\
\text { Visual impairment }\end{array}$ & $\begin{array}{c}64 \\
26 \\
30 \\
27 \\
3\end{array}$ & $\begin{array}{c}42.6 \\
17.3 \\
20 \\
18.0 \\
2.0\end{array}$ \\
\hline $\begin{array}{l}\text { Skin diseases } \\
\text { Skin inflammation } \\
\text { Skin sensitivity } \\
\text { Skin irritation } \\
\text { Dry skin } \\
\text { Burns } \\
\end{array}$ & $\begin{array}{c}58 \\
52 \\
22 \\
15 \\
3\end{array}$ & $\begin{array}{c}38.7 \\
34.7 \\
14.6 \\
10.0 \\
2.0\end{array}$ \\
\hline $\begin{array}{l}\text { Ears diseases } \\
\text { Ear inflammation } \\
\text { Hearing loss } \\
\text { Discharge from the ear } \\
\text { Hearing impairment }\end{array}$ & $\begin{array}{l}42 \\
62 \\
12 \\
34\end{array}$ & $\begin{array}{c}28.0 \\
41.3 \\
8.0 \\
22.6\end{array}$ \\
\hline
\end{tabular}


Table (4): Frequency distribution of ceramic workers regarding their present medical history $(n=150)$

\begin{tabular}{||l|c|c|}
\hline \multicolumn{1}{|c|}{ Present medical history } & No. & \% \\
\hline \hline Difficulty breathing & 103 & 68.7 \\
\hline Chronic cough & 112 & 74.7 \\
\hline Pain in the upper back & 80 & 53.3 \\
\hline Neck pain & 66 & 44.0 \\
\hline Lower back pain & 35 & 23.3 \\
\hline Shoulder pain & 29 & 19.3 \\
\hline Change in skin color & 14 & 9.3 \\
\hline
\end{tabular}

Table (5): Frequency distribution of studied workers regarding observational checklist of safety and sanitary work environment condition

\begin{tabular}{|c|c|c|c|c|}
\hline \multirow[t]{2}{*}{ Items } & \multicolumn{2}{|c|}{ Present } & \multicolumn{2}{|c|}{ Not Present } \\
\hline & No. & $\%$ & No. & $\%$ \\
\hline Good lighting for safety services & 11 & 7.3 & 139 & 92.7 \\
\hline Good ventilation & 54 & 36.0 & 95 & 64.0 \\
\hline $\begin{array}{l}\text { Good monitoring of workers to control noise when using } \\
\text { machines }\end{array}$ & 70 & 46.7 & 80 & 53.3 \\
\hline $\begin{array}{l}\text { The presence of thermometers to measure the temperature of } \\
\text { the place }\end{array}$ & 53 & 35.3 & 97 & 64.7 \\
\hline Floor clean , dry and free from dust & 42 & 28.0 & 108 & 72.0 \\
\hline Floor free from cracks and crevices & 44 & 29.3 & 106 & 70.7 \\
\hline Clean place and wide & 49 & 32.7 & 101 & 67.3 \\
\hline Water and soup are available for continuous hand washing & 65 & 43.3 & 85 & 56.7 \\
\hline Separate place for clothes change & 49 & 32.7 & 101 & 67.3 \\
\hline $\begin{array}{l}\text { Separate bathing and washing facilities away from clothes } \\
\text { change place. }\end{array}$ & 41 & 27.3 & 109 & 72.7 \\
\hline There is a special drying towel for each worker & 25 & 16.7 & 125 & 83.3 \\
\hline Wastes disposal and put baskets for it & 47 & 31.3 & 103 & 68.7 \\
\hline Arranging stairs and free from cracks & 49 & 32.7 & 101 & 67.3 \\
\hline Separate place for eating & 35 & 23.3 & 115 & 76.7 \\
\hline Near specific hospital or clinic for workers & 60 & 40.0 & 90 & 60.0 \\
\hline Available and complete first aid bag & 25 & 16.7 & 125 & 83.3 \\
\hline First aid kit is easy to reach by a worker & 42 & 28.0 & 108 & 72.0 \\
\hline Safety alarm for protection from hazards & 44 & 29.3 & 106 & 70.7 \\
\hline $\begin{array}{l}\text { Training persons to bring and used the tools in the work in a } \\
\text { timely manner }\end{array}$ & 65 & 43.3 & 85 & 56.7 \\
\hline There are more than one fire extinguisher in separate places & 64 & 42.7 & 86 & 57.3 \\
\hline $\begin{array}{l}\text { There are security personnel trained to use fire extinguishers } \\
\text { in nearby places }\end{array}$ & 44 & 29.3 & 106 & 70.7 \\
\hline There is a separate emergency exit known to the workers & 49 & 32.7 & 101 & 67.3 \\
\hline
\end{tabular}


Table (6): Relation between studied workers' total practices and their total knowledge

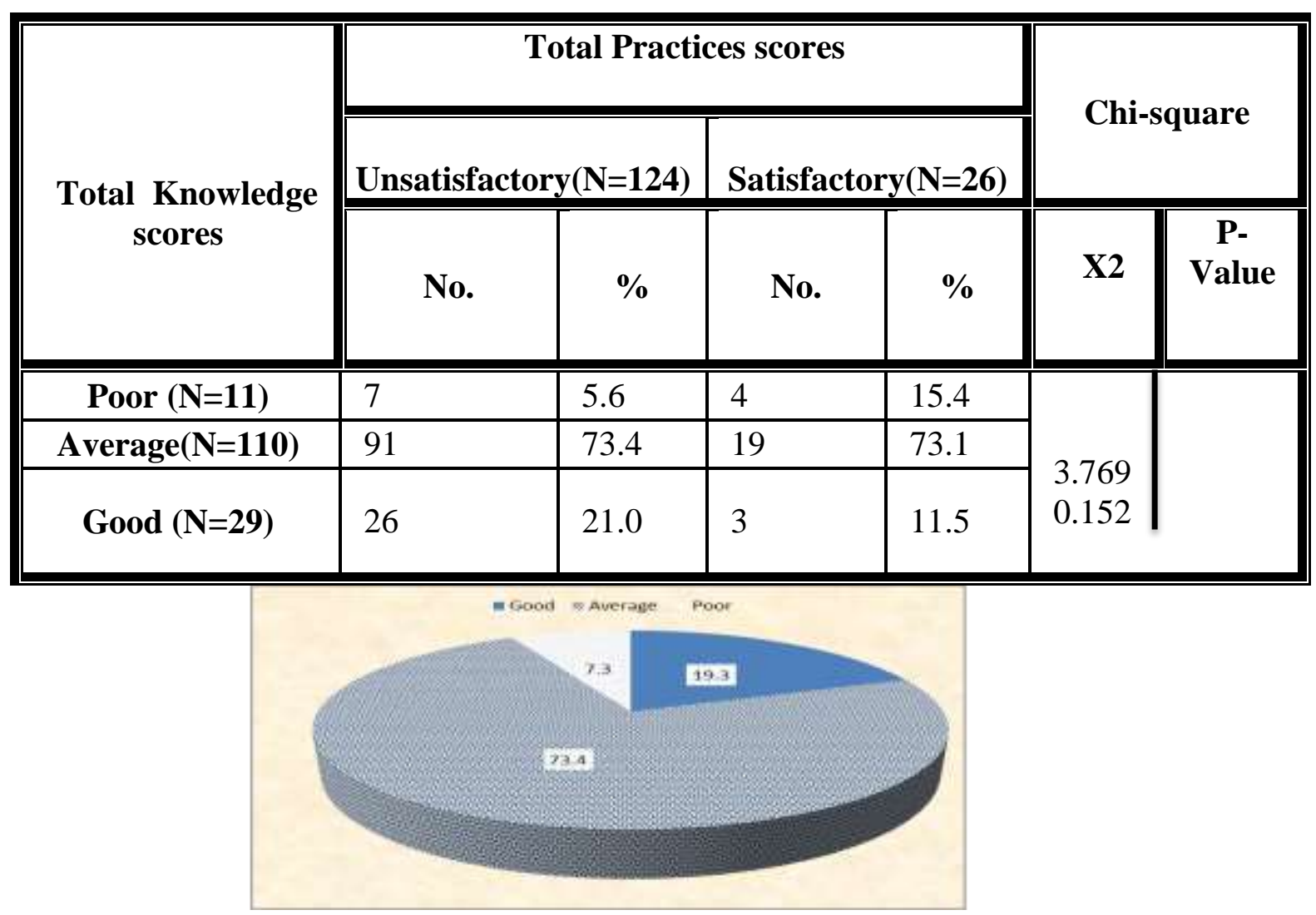

Figure (1): Percentage distribution of ceramic workers regarding their total knowledge about occupational health hazards $(\mathbf{n}=150)$.

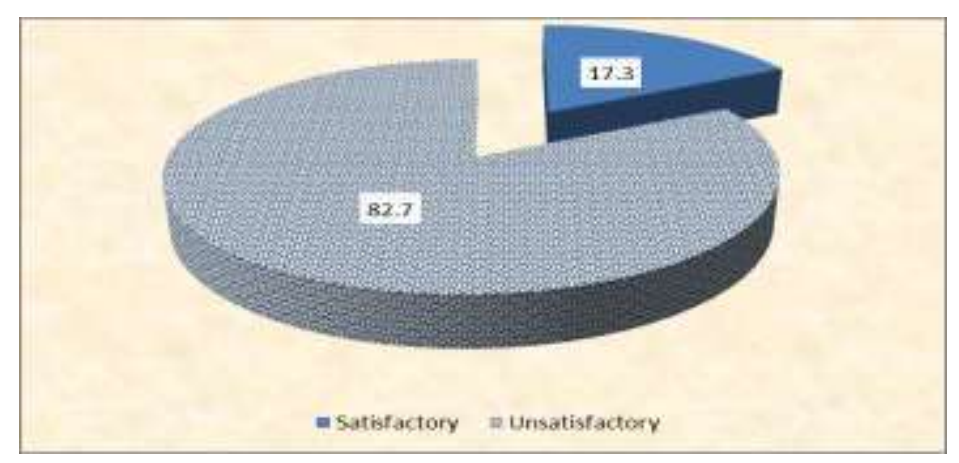

Figure (2): Percentage distribution of studied workers regarding their total practices to prevent occupational health hazard in Ceramic Factory. $(n=150)$.

Discussion

Occupational health is important because work plays a central role in people's lives, since most workers spend at least eight hours a day in the workplace. Occupational health hazard in Ceramic Factories are classified on the basis of biological, chemical, physical, psychological and an ergonomic property. That may have acute effects; 
Ceramic Factory is one of the most the most accidents industries (Hoke et al., 2018).

According to socio demographic characteristics of studied ceramic workers, the present study showed that more than two fifth of the studied ceramic workers their age was 30 years and more with mean age $32.54 \pm$ 8.47 years, and less than one third of them could read and write and more than one thirds of them had not enough income. These findings agreed with Ali (2017), who studied "Some health disorders among worker in ceramic industry" in Monufia $(n=160)$, who found that more than one third of the sample were 40 years old, one third could read and write, and two thirds had not enough income.

The current study revealed that, more than three quarters of the studied ceramic workers were living in rural area. This finding agreed with Reddy \& Yasbanet. (2018), who studied " Musculoskeletal disorders among municipal ceramic workers in India $(n=376)$ " who reported that nearly more than three quarters of the studied sample were lived in rural.

The present study showed that more than one fifth of the ceramic workers were married. This result disagreed with Alwadai (2018), who studied "The knowledge and practices of ceramic workers in Pakistan University, (n=110)", who reported that nearly three quarters of the studied sample were married.

As regards smoking; about more than half of the ceramic workers were smoking. This finding agreed with Awad (2018), who studied" Occupational hazards and preventive measures among workers in ceramic workers in Ain Shamies University $(n=285)$ " who reported that half of the ceramic workers were smoking, Also this finding disagreed with Aziz et al. (2018), who studied "Respiratory disorders in ceramic workers in Egypt " $(n=375)$, who reported that about more than three quarter of the ceramic workers were smoking. This might due to life pressures that workers faced.

The present study showed that more than three quarters of the studied ceramic workers worked for 6-8hours/day. This result was in the same line with Mostaghaci et al. (2018), who studied "effect of noise on hearing ability of five tiles in ceramic Factories workers in Yazd, Iran" $(n=354)$ They reported that three quarter of the studied ceramic workers worked for 6-8 hours/day. On other hand, the present study disagreed with Alwadai (2018), who found that more than three quarters of the studied sample worked for 12 hours/day. This might be due to the differences in factories polices and economic factors.

Regarding the years of experience, the present study showed that two fifth of the studied sample had 1-5 years of work experience at Ceramic Factory. This finding agreed with Halvani et al. (2018), who studied "Respiratory symptoms in tile and Ceramic Factory in Yazd, Iran" $(n=160)$. They reported that less than half of the studied sample had 1-5 years of work experience at Ceramic Factory.

Regarding the training courses which taken related to work in Ceramic Factory, the present study revealed that more than half of the studied ceramic workers had training courses on using of personal protective equipment. This result was in the same line with Mostaghaci et al. (2018), who found that half of the studied ceramic workers had training courses on using of personal protective equipment.

The current study revealed that less than half of the studied ceramic workers had only one training course in this Factory. This finding agreed with Halvani et al. (2018), 
who found that half of sample had only one course. On the other hand, the present study disagreed with Aziz et al. (2018), who found that more than three quarters of the studied sample had two training course. This might be due to the difference of system of the work in each Factory.

The current study revealed that more than one third of the sample had lung cancer. This finding agreed with Ali (2017), who reported that one third of the studied sample had lung cancer.

The current study revealed that less than half of the ceramic workers had irritation of the membrane of the eye, this finding agreed with Halvani et al (2018) who found that half of the studied sample had irritation of the membrane of the eye. This might due to not using eye goggle during work by more than half of workers and eye goggles restrict movement

The current study revealed that more than two fifth of the studied ceramic workers had hearing loss. This finding agreed with Ogido et al. (2019), who studied " prevalence of auditory and vestibular symptoms in workers with auditory complaints exposed to occupational noise in Mansoura university" in Egypt ( $\mathrm{n}=680$ ), who reported that more than one third of the studied sample had hearing loss. This might due to more than half of ceramic workers didn't use ear muffs during work.

The present study showed that-more than two thirds of the studied ceramic workers had chronic cough and less than two thirds of studied ceramic workers had difficulty breathing regarding their present medical history. These findings agreed with Halvani et al., 2018 who reported that more than half of the studied sample has cough and difficulty breathing, also this study finding agreed with Fahmy et al. (2019), who reported that three quarters of the studied sample had cough and difficulty breathing. This might be due to the fact the majority of workers didn't have courses about occupational health hazards and didn't use respiratory masks during work.

Regarding safety and sanitary work environment condition, the present study revealed that less than half of studied ceramic workers worked in Factory with good monitoring of workers to control noise when using machines. This result agreed with Fahmy et al. (2019), who found that half of the sample adapt with the noise of the machine.

The present study revealed that there was no statistical significant relation between the studied ceramic workers' total practices and their total knowledge. This finding was in the same line with Fahmey etal. (2019), who revealed that there was no statistically significant difference relation between the studied workers' total knowledge score and their total practices score. That because this result explained that no relation between knowledge scores of ceramic workers and total practice scores.

The present study revealed that less than one fifth of the studied workers had good total knowledge scores about occupational health hazards. This result agreed with Mostaghaci et al. 2018), who found that less than one quarters of the sample had good total knowledge scores about occupational health hazards. This might be due ceramic worker's level education which affects their knowledge.

Regarding studied ceramic workers total practices scores, the present study revealed that the majority of studied workers had 
unsatisfactory practices regarding prevention of occupational health hazards in Ceramic Factory. This finding agreed with Saad et al. (2016), who reported that more than half of the studied sample had unsatisfactory practices regarding prevention of occupational health hazard.

\section{Conclusion}

More than half of the studied ceramic workers had allergic rhinitis and sinusitis regarding past medical history in Ceramic Factory while less than three quarters of them had chronic cough regarding present medical history in Ceramic Factory. Less than three quarters of studied workers had average total knowledge scores regarding occupational hazards in Ceramic Factory and the minority of studied Ceramic Workers had poor total knowledge scores regarding occupational hazards. The majority of studied Ceramic Workers had satisfactory practices regarding prevention of occupational health hazard.

There was no statistically significant relation between the studied ceramic workers' total knowledge scores and their total practices score regarding occupational health hazards.

\section{Recommendations}

* Develop and implement training program for ceramic workers to improve their knowledge and practices toward occupational health hazards.

* Regular periodic screening for all ceramic workers for early detection of any health problems.

* Personal protective devices should be available to all departments in Ceramic Factory.

* This study needs to be replicated on a large sample to prevent occupational health hazards.

\section{Acknowledgment}

I would like to express my deepest thanks to the Ceramic Factory workers who shared in this study as their cooperation was of great value to accomplish this study

\section{References}

Abdel-Rasoul, G., Abu-Salem, M., ElShazly, H., Allam, H., and Abdel-Latif, A. (2015). Respiratory and auditory health disorders among workers in a ceramic Factory, Quesina City, Menoufia Governorate MenoufiaMedicalJournal,29(3), 779-84.

Ali, A. (2017). Some health disorder among workers in ceramic industry. master thesis. Faculty of Medicine, Monufia University. P:155-167.

Alwadai, H.(2018). Hearing protection devices: mining hearing loss preventionworkshop.Availabla at https://ww w.cdc.gov/niosh /mining /userfiles /hlp1/05hudak /workshops hearing protectors.pdf. Accessed on September, 2016.

Awad, W.(2018). Occupational hazards and preventive measures among workers in Ceramic Workers in Ain Shamies University. Available at https://www.cdc.gov/niosh/docs/2002129/pdf 12002-129.pdf. . Accessed on November, 2020.

Aziz, H., Ahmed, S., and Saleh, I. (2018). Respiratory hazards among Egyptian Ceramics Workers. Researcher, 2(6): 65-73. .

Colovic, G. (2018). Silicosis and coal workers' pneumoconiosis: imaging of the chest. National Library of Medicines; 1(59); 180-181.

Fahmy, F., Abdel-Hamid, M., Abbas, F., and El-Gazzar, R. (2019). Respiratory affection, alterations of some oxidative stress and autoimmune biomarkers among workers exposed to silica dust with and without silicosis in one of the Factories for refractories 
in Alexandria, Egypt. Egyptian journal of occupational medicine, 35(1): 1-21.

Friend, M., and Kohn, J. (2018). Fundamentals of occupational safety and health, $7^{\text {th }}$ ed.,London, Bernan 1 (3) p. 522

Halvani, J., Davenport, S., and Morgis, G., (2018). Respiratory symptoms in tile and Ceramic Factory in Yazd, Iran. The Scientific World Journal, Article 2 (6) :25-37.

Hoke, E. Ross, B. and Hoke, M. (2018). Auditory afterimage: tonotopic representation in the auditory cortex. neuroreport, 9(13), Pp 60-85..

Jain, A., Leka S, and Zwetsloot, G. (2018). Occupational health hazards among Flax Factories workers in Shubra Meles village. American Journal of Nursing Research; 5(6), 219-225.

Moursy, A., \& Sharaf, A., (2017).Vascular access care at inside-analysis gap; girls' compliance to infection prevention and control ways. iors journal of assistant and health science, 9(8), 236-256.

Mostaghaci, M., Mirmohammadi, S., Mehrparvar, A., Bahaloo, M., Mollasadeghi, A., and Davari, M. (2018). Effect of workplace noise on hearing ability in tile and ceramic industry workers in Iran: A 2Year Follow-Up Study. The Scientific World Journal, 23 (9) pages. Available at http://dx.doi.org/10.1155/2013/92373.

Accessed on June, 2016.

Moganti, P. (2016).Safety risk investigation of horizontal directional drillingprojectMScThesis,ClemsonUniversity, Availableat. http://tigerprints.clemson.edu/all theses/2451Clemson. Accessed on $2019 \mathrm{Jul}$ 22.

Noorian, C., Parvin ,N., and Mehrabi ,T. (2017): Workload and fatigue. Space Safety and Human Performance, 1st ed., chapter 3, p. 944. $\begin{array}{cccc}\text { Occupational } & \text { Safety } & \text { and } & \text { Health } \\ \text { Administration( } & \text { OSHA) } & \text { - } & \text { (2019). }\end{array}$

Ergonomics: the study of work. us department of laborAvailable at https://www.osha.gov/Publications/osha3125.p df. Accessed on April, 2019, at 9:00pm.

Ogido, R., Costa, E., and Machado, H. (2019). Prevalence of auditory and vestibular symptoms in workers with auditory complaints exposed to occupational noise in Mansoura university in Egypt journal of Public Health, 43(2), 377:80.

Pretty, J., Barton J., Pervez Z., Bragg R., Pencheon D., Wood C. and Depledge, $M$. (2016). The assessment of heat stress and heat strain in pardis petrochemical complex. International Journal of Occupational Hygiene, 5 (1), 6-11

Reddy, D., and Yasbanet, A. (2018). Musculoskeletal disorders among municipal ceramic workers in India. Available at http ://ceramics org/knowledge-center/learn-aboutceramics. Accessed on April, 2021

Ramos, K. Reilly, M., and Gardiner, J. (2018). Results of spirometry among individuals in a silicosis registry journal of occupational and environmental medicine, 52(12), 1173-8.

Saad, A., Radeal, A., and Aliger, H. (2016). The knowledge, attitudes and practices of workers who exposed to silicosis during work at Ain Shams University. Egyptian journal of occupational medicine, 30 (2), 193-216.

Smits, P., Hulshof, C., Bastiaanssen, M. and Van Balen, J. (2018). Time trends in musculoskeletal disorders attributed to work exposures in Ontario using three independent data sources. Journal of Occupational and Environmental Medicine, 72 (4), 252-257 


\section{مخاطر الصحة المهنية للعاملين في مصانع السيراميك}

أسماء فتحى محمود - محبوبه صبحي عبد العزيز - تيسير حميدو أبو سريع

تحتوي مخاطر الصحة المهنية علي أشكال متنوعة من المخاطر، ونتمل المخاطر الكيميائية و الفيزيائية والبيولوجية والنفسية وهدفت هذه الدراسة الي تقييم مخاطر الصحة المهنية للعاملين في مصانع السير اميك. حيثث أجريت هذه الدراسة بمصنع السير اميك بمدينة قويسنا بمحافظة المنوفية وقد تم استخدام العينة المنتظمه في هذه الدراسة لاختيار العمال في مصنع السير اميك ، حيث كثفت النتائج ان لدى أقل من ثلاثة أرباع العمال لديهم معلومات متوسطه فيما يتعلق بالمخاطر المهنية في مصنع السير اميك و ان معظم العمال لديهم ممارسات مرضية فيما يتعلق بالوقاية من مخاطر الصحة المهنية. كما أوصت الدراسة بأهمية تطوير وتنفيذ برنامج تدريبي لعمال السير اميك لتحسين معلوماتهم وممارساتهم تجاه مخاطر الصحة المهنية. 